\title{
DEVELOPMENT AND VALIDATION OF RP- HPLC METHOD FOR THE SIMULTANEOUS ESTIMATION OF TRAMADOL HYDROCHLORIDE AND DICYCLOMINE IN BULK AND PHARMACEUTICAL FORMULATION
}

\author{
SHAILESH T. DONDA, VISHAL B. BAVISKAR, SANJAY B. BARI, PRASHANT K. DESHMUKH, DARSHAN S. \\ DEORE, NAYANDIP M. GIRASE, ZAMIR G. KHAN, PRAVIN O. PATIL*
}

Department of Quality Assurance, H. R. Patel Institute of Pharmaceutical

Education and Research, Karwand Naka, Shirpur. Dist. Dhule 425405 (M.S.)

\begin{abstract}
A simple, specific, accurate and precise reversed phase high pressure liquid chromatography (RP-HPLC) method has been developed for the simultaneous estimation of tramadol hydrochloride (TRA) and dicyclomine (DCY) in bulk and tablet dosage form. Chromatography was carried on Phenomex Gemini $\mathrm{C}_{18}$ column $(4.6 \times 250 \mathrm{~mm}, 5 \mu$ particle size) using mixture of methanol, acetonitrile and $0.1 \%$ triethylamine (TEA) pH 3.0 (adjusted with orthophophoric acid) in the ratio of 35:5:60 $(\mathrm{v} / \mathrm{v} / \mathrm{v})$ respectively as a mobile phase. The flow rate $1.0 \mathrm{~mL} \mathrm{~min}^{-1}$ and detection wavelength $275 \mathrm{~nm}$ was selected for the present study. The retention time of tramadol hydrochloride and dicyclomine were $4.13 \mathrm{~min}$ and $9.06 \mathrm{~min}$ respectively. The linear regression analysis data for the calibration plots showed a good linear relationship over the concentration range of 50-300 $\mu \mathrm{g} \mathrm{mL} \mathrm{m}^{-1}$ for tramadol hydrochloride and 10-60 $\mu \mathrm{g} \mathrm{mL} \mathrm{m}^{-1}$ for dicyclomine. The proposed method was validated with respect to linearity, precision, accuracy, specificity and robustness. The proposed method was found to be simple, rapid, accurate, precise and reproducible. Thus it can be applied for routine quality control analysis of tramadol hydrochloride and dicyclomine in tablet dosage form.
\end{abstract}

Keywords: Dicyclomine, RP-HPLC, Tramadol hydrochloride

\section{INTRODUCTION}

Tramadol hydrochloride (TRA) is chemically cis-2-[(dimethylamino) methyl]-1-(3-methoxyphenyl) cyclohexanol (Figure 1).The TRA is nonsteroidal anti-inflammatory drug used for treating moderate to severe pain. It is also used to treat postoperative, dental, cancer and acute musculoskeletal pain and as an adjuvant to NSAID therapy in patients with osteoarthritis ${ }^{1,2}$. Chemically, Dicyclomine hydrochloride (DCY) is 2-(diethyamino) ethyl 1-cyclohexylcyclohexane-1-carboxylate (Figure 2). It is anticholinergic drug used to treat a certain type of intestinal problem called irritable bowel syndrome and it helps to reduce the symptoms of stomach and intestinal cramping. It has little effect on glandular secretion or the cardiovascular system ${ }^{3,4}$.

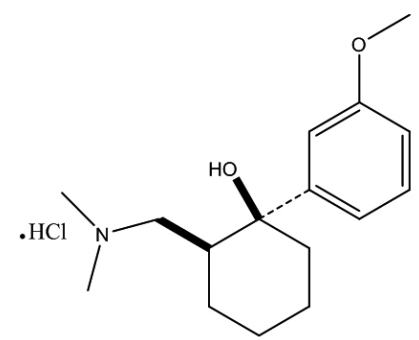

Figure 1. Chemical structure of Tramadol hydrochloride.

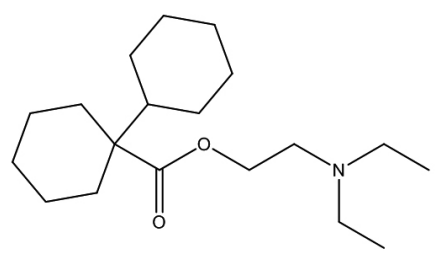

Figure 2. Chemical structure of Dicyclomine.

Numerous UV, HPLC and HPTLC based methods have been reported for the estimation of TRA and DCY alone as well as in combination with other drugs in pharmaceutical dosage forms. The various reported methods were, viz. UV ${ }^{5-11}$, HPLC $^{4,12-17}$ and HPTLC ${ }^{18-25}$ for estimation of TRA and DCY alone and in combination with other drugs. The RP-HPLC ${ }^{26}$ and UV-Spectroscopic ${ }^{27}$, ${ }^{28}$ methods have been studied for determination of TRA and DCY in bulk and in pharmaceutical dosage form. The aim of our study was to develop a simple, rapid, accurate and precise RP-HPLC method for simultaneous estimation of TRA and DCY by using easily available resources.

\section{EXPERIMENTAL}

\section{Materials and reagents}

Gift sample of TRA was procured from Vapi Organic Chemicals Pvt. Ltd. (India) and DCY was procured from Alaric Healthcare Pvt. Ltd. (India). HPLC grade methanol and acetonitrile was purchased from Merck chemicals, India. Water used was double distilled and filtered through a $0.45 \mu \mathrm{m}$ filter. Commercial tablet formulation containing $20 \mathrm{mg}$ DCY and $100 \mathrm{mg}$ TRA was purchased from local market and used for present study.

Instrumentation and materials

To develop a RP-HPLC method for quantitative estimation of TRA and DCY, an isocratic Shimadzu instrument with Phenomex Gemini $\mathrm{C}_{18}$ column (4.6 $\times 250 \mathrm{~mm}, 5 \mu$ particle size) was used. Ezechrome Elite software was applied for data collecting and processing.

Chromatographic conditions

The chromatography elution was carried out in the isocratic mode using a mobile phase consisting of methanol, acetonitrile and $0.1 \%$ TEA $(\mathrm{pH} 3.0, \mathrm{pH}$ adjusted with orthophosphoric acid) in a ratio of 35:5:60 $(v / v / v)$. The mobile phase was passed through $0.45 \mu \mathrm{m}$ membrane filter and degassed by sonication. The flow rate was maintained at $1.0 \mathrm{~mL} \mathrm{~min}{ }^{-1}$ and the measurements were made at $275 \mathrm{~nm}$. Phenomex Gemini $\mathrm{C}_{18}$ column $(4.6 \times 250 \mathrm{~mm}, 5 \mu$ particle size $)$ was used and the RP-HPLC system was kept at ambient temperature.

Preparation of standard stock and working solution

A stock solution containing $1000 \mu \mathrm{g} \mathrm{mL} \mathrm{L}^{-1}$ of TRA and DCY were prepared separately by dissolving in mobile phase and sonicated for $3 \mathrm{~min}$. From this stock solution, a working standard solution containing 50-300 $\mu \mathrm{g} \mathrm{mL}^{-1}$ of TRA and $10-60 \mu \mathrm{g} \mathrm{mL}^{-1}$ of DCY were prepared by serial dilutions.

\section{Method validation}

After method development, the validation of the current method has been performed in accordance with ICH guidelines. The method was validated for linearity, precision, accuracy, limit of quantification (LOQ), limit of detection (LOD) and robustness ${ }^{29}$.

\section{RESULT AND DISCUSSION}

\section{Optimization of mobile phase}

The existing method for estimation of TRA and DCY (26) utilized buffer in the mobile phase which may affect column efficiency. Therefore, there is enough scope for the optimization of mobile phase for estimation of TRA and DCY. Firstly, the reversed-phase column was tested by column performance and then selected for the method development. The system suitability studies were carried out as specified in ICH guidelines. Several trials were performed using plenty of mobile phases with their different proportions and $\mathrm{pH}$, finally methanol, acetonitrile and $0.1 \%$ TEA $(\mathrm{pH} 3.0$ adjusted with orthophosphoric 
acid) in the ratio of 35:5:60 $(v / v / v)$ respectively was selected as optimized mobile phase which gave good resolution and acceptable system suitability parameters like retention time $\left(t_{R}\right)$, theoretical plates, tailing factor and resolution. The flow rate was kept at $1.0 \mathrm{~mL} \mathrm{~min}{ }^{-1}$ and injection volume was kept $20 \mu \mathrm{L}$. The effluents were detected at $275 \mathrm{~nm}$ by photo diode array (PDA) detector. The chromatogram of working standard solution is shown in Figure 3.

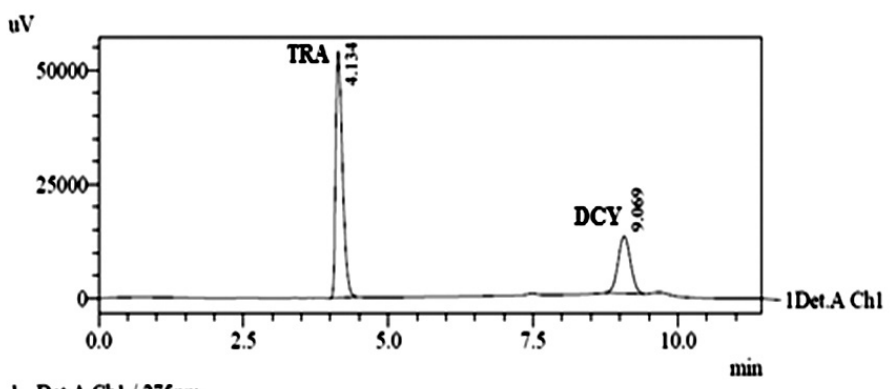

I Det.AChl / $275 \mathrm{~nm}$

Figure 3. Chromatogram of TRA and DCY

\section{System Suitability Parameter}

The values of theoretical plates, tailing factor and resolution were shown in Table 1 . The values obtained demonstrate the suitability of the system for the analysis of this drug combination. Further more in existing method (26) retention times for TRA and DCY are very near close to the unretained peak with poor resolution in contrast our developed method retention times for TRA and DCY are far away from unretained peak having greater resolution and maximum theoretical plates which are prerequisite for RP-HPLC method development.

Table 1: Results of system suitability.

\begin{tabular}{|c|c|c|c|c|}
\hline Parameters & $\begin{array}{c}\text { Retention } \\
\text { time }\left(\mathbf{t}_{\mathbf{R}}\right)\end{array}$ & $\begin{array}{c}\text { Theoretical } \\
\text { plates }(\mathbf{N})\end{array}$ & $\begin{array}{c}\text { Resolution } \\
\text { (Rs) }\end{array}$ & $\begin{array}{c}\text { Tailing } \\
\text { factor }(\mathbf{T})\end{array}$ \\
\hline TRA & 4.13 & 5441 & 0.00 & 1.66 \\
\hline DCY & 9.06 & 8212 & 15.80 & 1.06 \\
\hline
\end{tabular}

\section{Validation of RP - HPLC method}

Linearity

Every $20 \mu \mathrm{L}$ of the working standard solution of TRA in the concentration range of 50-300 $\mu \mathrm{g} \mathrm{mL}^{-1}$ and for DCY in the concentration range of 10-60 $\mu \mathrm{g}$ $\mathrm{mL}^{-1}$ were injected three times into the chromatographic system. Calibration curves of TRA and DCY were obtained by plotting the mean peak area versus the injected concentration of TRA and DCY. The linearity data and calibration curve were shown in Figure 4.
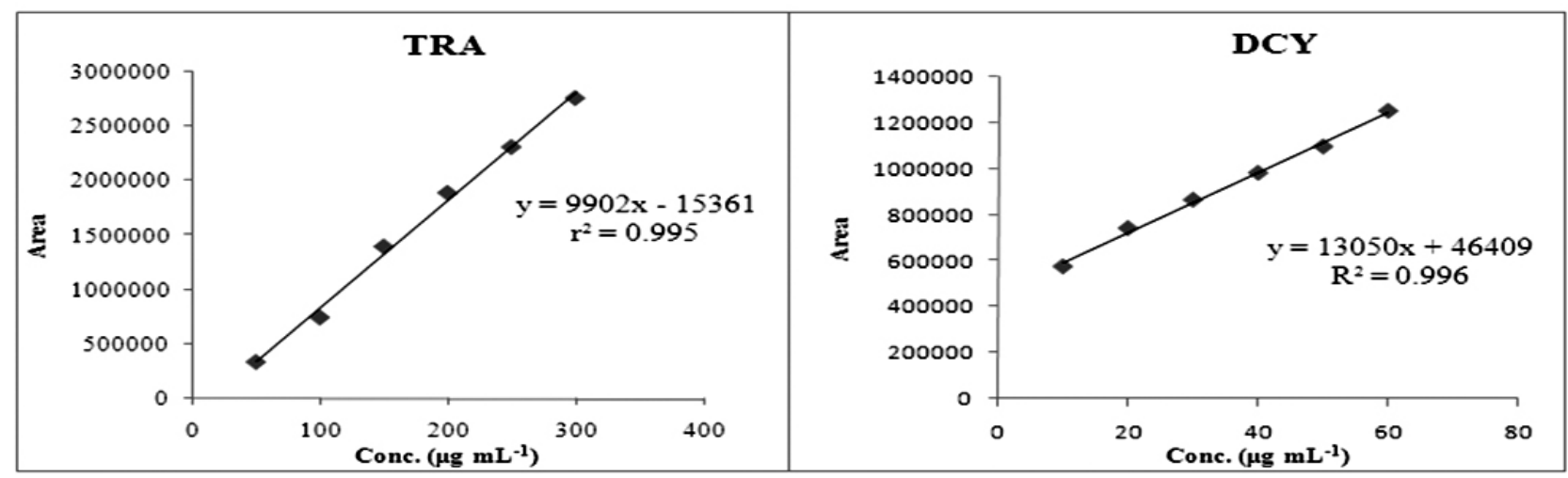

Figure 4. Calibration curve of TRA and DCY

Accuracy

The recovery of the standard solutions was done by adding them to preanalyzed sample solution at three different levels i.e. $80 \%, 100 \%$ and $120 \%$ separately to study the accuracy of the proposed method. The accuracy data were shown in Table 2 .

Table 2: Results of recovery study.

\begin{tabular}{|c|c|c|c|c|c|}
\hline Drugs & $\begin{array}{c}\text { Amount } \\
\text { Added } \\
(\%)\end{array}$ & $\begin{array}{c}\text { Amount } \\
\text { Recovery } \\
(\%)\end{array}$ & $\begin{array}{c}\text { Mean } \\
\text { Recovery }(\%) \\
(n=3)\end{array}$ & S.D & \%R.S.D \\
\hline \multirow{3}{*}{ TRA } & 80 & 99.14 & \multirow{3}{*}{99.75} & 1.85 & 1.03 \\
\hline & 100 & 101.38 & & 1.53 & 0.75 \\
\hline & 120 & 98.74 & & 2.67 & 1.22 \\
\hline \multirow{3}{*}{ DCY } & 80 & 101.30 & \multirow{3}{*}{101.11} & 0.61 & 1.67 \\
\hline & 100 & 100.92 & & 0.62 & 1.53 \\
\hline & 120 & 100.12 & & 0.80 & 1.79 \\
\hline
\end{tabular}

n- Number of estimations
Precision

The precision of the method was demonstrated by repeatability study, interday precision and intra-day precision. In the repeatability study, six replicates of the same concentration of working standard solutions were prepared and injected and chromatograms were recorded. The results obtained were shown in Table 3. In inter-day precision and intra-day precision, three replicates of three different concentration of working standard solution were prepared and injected and chromatograms were recorded. The results obtained were shown in Table 4.

Table 3: Results of repeatability study.

\begin{tabular}{|c|c|c|c|}
\hline Drugs & Mean Area $(\mathbf{n}=\mathbf{6})$ & S.D & \%R.S.D \\
\hline TRA & 828293 & 11432.48 & 1.38 \\
\hline DCY & 726507 & 4061.94 & 0.55 \\
\hline
\end{tabular}

n- Number of estimations 
Table 4: Results of intra-day and inter-day precision

\begin{tabular}{|c|c|c|c|c|c|}
\hline & Drug & $\begin{array}{l}\text { Amount Taken } \\
\quad\left(\mu \mathrm{g} \mathbf{m L}^{-1}\right)\end{array}$ & $\begin{array}{l}\text { Mean Amount Found } \\
\left(\mu \mathrm{g} \mathbf{m L}^{-1}\right)(\mathbf{n}=\mathbf{3})\end{array}$ & S.D & \%R.S.D \\
\hline \multirow{6}{*}{ Intraday } & \multirow{3}{*}{ TRA } & 100 & 98.31 & 1.62 & 1.52 \\
\hline & & 150 & 150.85 & 1.78 & 0.75 \\
\hline & & 200 & 203.71 & 2.92 & 1.10 \\
\hline & \multirow{3}{*}{ DCY } & 20 & 19.21 & 2.14 & 1.60 \\
\hline & & 30 & 30.91 & 1.75 & 1.38 \\
\hline & & 40 & 39.12 & 1.87 & 1.03 \\
\hline \multirow{6}{*}{ Interday } & \multirow{3}{*}{ TRA } & 100 & 99.10 & 1.11 & 1.03 \\
\hline & & 150 & 148.80 & 2.36 & 1.66 \\
\hline & & 200 & 197.71 & 1.69 & 1.52 \\
\hline & \multirow{3}{*}{ DCY } & 20 & 21.37 & 1.53 & 1.49 \\
\hline & & 30 & 30.54 & 1.56 & 1.20 \\
\hline & & 40 & 41.00 & 2.43 & 0.95 \\
\hline
\end{tabular}

\section{n- Number of estimations}

Limit of detection (LOD) and Limit of quantification (LOQ)

The LOD and LOQ values of TRA and DCY by the proposed method were determined using the calibration standard. LOD and LOQ were calculated as $3.3(\sigma / \mathrm{S})$ and $10(\sigma / \mathrm{S})$ respectively, where ' $\sigma$ ' is the standard deviation of the peak areas of the drug $(\mathrm{n}=3)$ and ' $\mathrm{S}$ ' is the slope of the corresponding calibration plot.

The LOD and LOQ were 6.57 and 19.92 for TRA and 3.09 and 9.38 for DCY respectively.

Robustness

Robustness of the method was determined by carrying out the analysis under different varied condition like mobile phase, flow rate and detection wavelength. The results of robustness study were shown in Table 5.

Table 5: Results of robustness study

\begin{tabular}{|c|c|c|c|c|c|}
\hline \multirow{2}{*}{ Parameter } & \multirow{2}{*}{ Variation } & \multicolumn{2}{|c|}{ Retention Time $\left(t_{R}\right)$} & \multirow{2}{*}{$\begin{array}{c}\text { TRA (mean area) } \\
(\mathrm{n}=3)\end{array}$} & \multirow{2}{*}{$\begin{array}{c}\text { DCY (mean area) } \\
(\mathrm{n}=3)\end{array}$} \\
\hline & & TRA & DCY & & \\
\hline \multirow{3}{*}{ Flow rate } & $0.9 \mathrm{~mL}$ & 4.26 & 9.21 & 733732 & 648506 \\
\hline & $1.0 \mathrm{~mL}$ & 4.13 & 9.06 & 814124 & 722867 \\
\hline & $1.1 \mathrm{~mL}$ & 3.96 & 8.86 & 746838 & 772904 \\
\hline \multirow{3}{*}{ Mobile phase } & $32: 5: 63$ & 4.24 & 9.36 & 762948 & 682495 \\
\hline & $35: 5: 60$ & 4.13 & 9.06 & 823941 & 735972 \\
\hline & $38: 5: 57$ & 4.02 & 8.87 & 831975 & 759124 \\
\hline \multirow{3}{*}{ Wavelength } & 273 & 4.21 & 9.18 & 826725 & 713428 \\
\hline & 275 & 4.13 & 9.06 & 797371 & 724411 \\
\hline & 278 & 3.98 & 8.92 & 768504 & 694644 \\
\hline
\end{tabular}

n- Number of estimations

Assay

Twenty tablets, each containing $100 \mathrm{mg}$ of TRA and $20 \mathrm{mg}$ of DCY, were powdered finely. A quantity of powder containing $50 \mathrm{mg}$ of TRA and $10 \mathrm{mg}$ of DCY was transferred to a $10 \mathrm{~mL}$ volumetric flask and volume was made upto the mark with mobile phase. The solution is filtered through membrane filter paper ( 0.45 $\mu \mathrm{m})$ and sonicated for $10 \mathrm{~min}$. This solution was again diluted with mobile phase to give a final concentration mentioned in the tablet samples. The percent drug content of tablets obtained by the proposed method for TRA and DCY was found to 99.38 and 101.47 respectively. The results are given in Table 6 .

Table 6: Results analysis of marketed tablets.

\begin{tabular}{|c|c|c|c|}
\hline Component & $\begin{array}{c}\text { Labelled } \\
\text { Amount (mg) }\end{array}$ & $\begin{array}{c}\text { Mean Amount } \\
\text { Found (mg) (n=6) }\end{array}$ & $\begin{array}{c}\text { \%Amount Found } \\
\text { Mean (n=6) }\end{array}$ \\
\hline TRA & 100 & 99.38 & 99.38 \\
\hline DCY & 20 & 20.29 & 101.47 \\
\hline
\end{tabular}




\section{Specificity}

The ability of an analytical method to unequivocally assess the analyte in the presence of other components like impurities, degradation product and excipients can be verified by evaluating specificity.

The specificity of the RP- HPLC method was studied by the entire separation of TRA and DCY by taking into account system suitability parameters like retention time $\left(\mathrm{t}_{\mathrm{R}}\right)$, capacity factor $(\mathrm{k})$, tailing or asymmetrical factor (T) and resolution. Also, it was confirmed by spectra of drug standard and drug sample.

Specificity proved no interference due to any unknown excipients of formulation at the retention times of TRA and DCY. The peaks obtained were sharp and had clear baseline separation.

\section{CONCLUSION}

A novel RP-HPLC method has been developed for the simultaneous estimation of TRA and DCY in bulk and tablet dosage form. In this method sample preparation is simple and the time of analysis is short (less than 10 $\mathrm{min}$ ). The method was found to be simple, precise accurate, specific and linear over the concentration range tested $(80-120 \%)$ with a correlation coefficient of 0.995 for TRA and 0.996 for DCY. The proposed method was validated and can be effectively used for routine analysis of TRA and DCY in combined dosage form.

\section{REFERENCES}

1.- British Pharmacopoeia. The Stationary Office Medicinal and Pharmaceutical Substances, Vol.2, London, 2060, 2009.

2.- http://www.drugbank.ca/drugs/DB00193 (Accessed on 15/03/2013).

3.- British Pharmacopoeia. The Stationary Office Medicinal and Pharmaceutical Substances (A-I), Vol.1, London, 649, 2009.

4.- D. Prajapati, H. Raj, Int. J. Bio. Sci, 3, 611-625, (2012).

5.- M. Moradiya, K.Vadalia, Z.R Dedania, Inventi Rapid: Pharm. Ana. \& Qual. Ass.,425-429,(2012).

6.- R, Sawant, L. Bhangale, R.Joshi,P. Lanke, J. Chemical Metrology, 4,21-27,(2010).

7.- ToralInes M, J. of the Chilean Chemical Society,53,1543-1547,(2008).

8.- D.Gharge, P.Dhabale,International J. of Pharm Tech Research,2,1119-1123,(2010).

9.- K.N. Setty, T. Ramachar, I.E. Chakravarthy,K. Prabhavathi,Chemical Science Transactions, 1,317-320,(2012).

10.- M. Puranik, A. Hirudkar, S.J. Wadher, P.G. Yeole,Indian J Pharm Sci,68,737-739,(2006).

11.- A. Patel, J.Patel, P. Patel,D. Baria, D.Bhavsar, Inventi Rapid: Pharm Analysis \& Quality Assurance,532,(2012).

12.- S.R.Lokhande, S.M. Mhetre, S.S. Pekamwar,T.M. Kalyankar,World J. of Pharmacy and Pharmaceutical Sciences, 1,968-980,(2012).

13.- L. Singh,S.Nanda,Res J Pharm Technol,3,562-565,(2010).

14.- W.F. Kartinasari, T. Palupi, G. Indrayanto ,737-744,(2005).

15.- A. Kucuk,Y. Kadioglu,Farmaco,60,163-169,(2005).

16.- P.K. Kachhadia, A.S.Doshi,V.R.Ram,H.S. Joshi,Chromatograph ia,68,997-1001,(2008).

17.- P. Chandra,A.S Rathore, S. Lohidasan,K.R. Mahadik, SciPharm,80,337-351,(2012).

18.- A.R. Keer, S.S. Havele, K.H. Gopani, S.R. Dhaneshwar,Der Pharma Chemica,3,549-556,(2011).

19.- S.E. Potawale,R.K. Nanda,V.V. Bhagwat,S.C.Hamane, R.S. Deshmukh, K. Puttamsetti,J Pharm Res,4,3116,(2011).

20.- D.A. Nanaware, V.K. Bhusari, S.R. Dhaneshwar,International J. of Pharmacy \& Technology,4,4392-4403,(2012).

21.- S.R. Dhaneshwar,A.R. Keer,S.S. Havele,K.H. Gopani,Res J Pharm Biol Chem Sci,2,314-324,(2011).

22.- P. Desai, A. Captain, S. Kamdar,International J. of PharmTech Research, 4,1261-1265,(2012).

23.- P.P. Apshingekar, P.V. Mahadik, S.R. Dhaneshwar,Der Pharmacia Lettre,2,28-36,(2010).

24.- C. Roosewelt, N. Harihrishnan, V. Gunasekaran,S. Chandrasekaran,V. Haribaskar, B. Prathap,Asian J. of Chemistry,22,850-854,(2010).

25.- Z. Ebrahim,D. Balalau, D.L.Baconi, C.M. Gutu,M. Ilie,Farmac ia,59,381-387,(2011).

26.- H. Raval, R. Radadiya,K. Khant, H. Bhuva , A. Mavani ,Inventi Rapid,Pharm Ana. \& Qual. Assur., 973-976, (2013).
27.- H. Raval , S. Patel , A. Kapadiya ,D. Viradiya ,M. Ramanuj,Inventi Rapid: Pharm Ana. \& Qual.Assur.,977-980,(2013).

28.- H. Raval, R.Patel ,S.Gorasiya, J. Sangani, Rokad,Inventi Rapid: Pharm Ana. \& Qual. Assur.,981-984,(2013).

29.- ICH Harmonized Tripartite Guideline, Q2 (R1): Validation of Analytical Procedures: Text and Methodology. November 2005. 